\title{
The relationship between emotional intelligence, self efficacy and prosocial behaviour on interpersonal conflict management
}

\author{
Marieta Gaol *) \\ Universitas Negeri Yogyakarta \\ *)Corresponding author, $\equiv$ e-mail: marietaefrianti1991@gmail.com
}

\begin{abstract}
This study aimed to determine influence of emotional intelligence, self efficacy and prosocial behaviour on interpersonal conflic management of Guidance and Counseling student at University of Yogyakarta. This research method is quantitative with an ex-post facto type which takes a sample by using proportional random sampling technique. The sample consisted of 40 students of Universitas Negeri Yogyakarta, 126 students of Ahmad Dahlan University, 38 students of Sanata Dharma University, 66 students of PGRI University Yogyakarta, 21 students of Yogyakarta University of Technology, 5 students of Mercu Buana University Yogyakarta and 39 students of IKIP PGRI Wates who were all students of Guidance and Counseling semester IV. Data of emotional intelligence, self efficacy, prosocial behaviour and interpesonal conflic management is taken by using scale. Reliability Test used technique of Cronbach's alpha, obtained $\mathrm{p}=0.929$ for emotional intelligence variable, $p=0.917$ for self efficacy variable, $p=0.915$ for prosocial behaviour variable, and $\mathrm{p}=0.849$ for variable of interpersonal conflic management. There was a positive and significant correlation between emotional intelligence, self efficacy and prosocial behaviour and interpersonal conflic management, with correlation cooficient 0.559 , obtained $\mathrm{p}=0.000$ and effective contribution equal to $31.3 \%$.
\end{abstract}

Keywords: emotional intelligence, self efficacy, prosocial behavior, interpersonal conflic management, guidance and counseling student

How to Cite: Gaol, M. (2018). The relationship between emotional intelligence, self efficacy and prosocial behaviour on interpersonal conflict management. Couns-Edu: International Journal of Counseling and Education, 3(4): pp. 121-125. DOI: https://doi.org/10.23916/0020180316830

(c) (i) This is an open access article distributed under the Creative Commons Attribution License, which permits unrestricted use, distribution, and reproduction in any medium, provided the original work is properly cited. (C2018 by author.

\section{Introduction}

The Students in late adolescence will progress towards early adult development. Adolescent development is a cyclical process in human life a benchmark of individual happiness and success (Santrock,2003:26). Students who are able to prepare themselves in late adolescence will determine the individual's readiness towardearly adult development. Papalia, et al (2009 : 115- 210) states thatyoung adults range from 18-21 years. Students will choose majors of interest from a wide range of majors that colleges offer. Student activity in college is following lectures and self-development activities .Encounter students with the people around him as well as facing a variety of new characteristics. Difficulty in accepting points of view and behavior patterns causes students to experience obstacles and blamethe people around them. Barriers often arise they want to interactdirectly for example by meeting and face to face, or indirectly for example through social media. Interpersonal conflict happens to be oneof the 
problems that can hinder student relation. one of the solutions is having interpersonal conflict management. Interpersonal conflict management is needed to assist students in determining the rightattitude in the face of interpersonal conflict.

Good conflict management skills will be a positive value for students will grow and be accepted intheir environment. Conversely, poor student conflict management brings increasingly difficult situations and obstacles to its development. According to Thomas and Kilmann (1976:8) in interpersonal conflict management individuals have cooperative capabilities shown in aspect sofaccommodatio, compromise, and collaboration. Researchers limithe three aspects of interpersonal conflict management to students. Good conflict management is a way to escape from the conflict. According to Goleman (Martin , 2007:30) that the management ofinterpersonal conflict is one of the social skills in the individual that isinfluenced by the awareness within the individual one of them related toemotional awareness, has self-management related to individual selfconfidence one of them is the belief to achieve success or achievement , and has an initiative in providing services to people around them throughprosocial behavior. According to Goleman (2009:59) individuals who have emotional intelligence able to be able to recognize emotions them selves, manage emotions, motivate your self, recognize theemotions of others, and foster relationships with others . Students areexpected to learn to apply all dimensions of emotional intelligence so that they are ready to take decisions in the face of conflict situations. Students ' efforts to become individuals who have positive interpersonal conflicts require self-regulation to be ready for future situations. One of them is through self efficacy, have the endurance andability to achieve the goals or achievements desired .Proosialbehavioris an individual action to provide assistance to others without receiving rewards. According to Stenberg and Mussen (Dayaksini and Hudaniah, 2002:87) one's efforts to prosocial behavior include sharing, cooping, helping, donating and honesty .

Interviews with 7 students 4 experienced low self efficacy, among them refusing to attend classes various reasons to avoid questionsand group tasks. Students give the assumption that if the task by friends of the group. The task that should be one of responsibility, becomes a burden for the group. This method illustrates that the individual has not had self efficacy to plan him selfinsolving the problems encountered. Furthermore, the students do not experience obstacles in running the lecture. Students have the ability to manage emotions when there is a force to do group work. By giving assertiveness to be done together, and give confidence in friends to tryto do the tasks with the potential they have. Positive dynamics areexpected to occur interpersonal interaction on university guidance and counseling students in Yogyakarta. According to Winkel (2006:184-186) the personality qualities that a counselor must possess are:(1) knowing himself, (2) understanding others and (3) having good communication skills with others. If the counselor is ready to deal with situations of conflict that occur from within himself then he was ready to deal with situations of conflict that arise from the environment.

Based on the fact that guidance and counseling students have problems related to emotional intelligence,self efficacy, prosocial behavior and interpersonal conflict management, so that the counselor candidate is expected to have good personality quality and have the ability to assist the counselee optimally. this evidence is shown based on interviews conducted by researchers. In this research we want to know the relationship of emotional intelligence, self efficacy and prosocial behavior with interpersonal conflict management of university guidance and counseling students in Yogyakarta

\section{Method}

This research method is quantitative research using ex-post facto type. The study population is all students of Guidance and Counseling semester 4 at university in Yogyakarta which amounted to 670 students. From the amount of research, the sample is taken as much as $50 \%$ by using Proportional Random Sampling technique considering the number of students Guidance and Counseling at each university is different so that the total sample used in this study is 335 students. The instrument of data collection using the scale of emotional intelligence with $\alpha 0.929$ item reliability, self efficacy scale with $\alpha$ 0.917 , prosocial behaviour scale with $\alpha 0.915$ and conflic interpersonal management scale with $\alpha 0.849$. The data obtained were analyzed using descriptive data analysis technique and partial regression test. 


\section{Results and Discussions}

The results of the data collection of the four variables are presented as shown below:

Table 1. Classification of Student Emotional Intelligence Scores

\begin{tabular}{llll}
\hline Score Range & Category & Total (Student) & Percentage (\%) \\
\hline $\mathbf{1 3 1 - \mathbf { 1 5 6 }}$ & Very High & 13 & 4 \\
$\mathbf{1 1 0}-\mathbf{1 3 0}$ & High & 117 & 35 \\
$\mathbf{8 8}-\mathbf{1 0 9}$ & Medium & 149 & 44 \\
$\mathbf{6 7 - 8 7}$ & Low & 52 & 16 \\
$\mathbf{3 9 - 6 6}$ & Very Low & 4 & 1 \\
Total & & 335 & 100 \\
\hline
\end{tabular}

Table 1 shows the variation in the level of emotional intelligence held by students of Guidance and Counseling at the University of Yogyakarta in the academic year 2016/2017. Based on the data in the table it can be seen that there are 4 students or $1 \%$ who have emotional intelligence in very low category, 52 students or $16 \%$ categorized low, 149 students or $44 \%$ moderate category, 117 students or $35 \%$ categorized high and 13 students or $4 \%$ categorize very high. The tendency of aspects of students' emotional intelligence Guidance and Counseling at university in Yogyakarta in 2017/2018 academic year can be observed through five aspects: 1) the aspect of recognizing self-emotions 2) aspects of managing emotions 3) self-motivating aspects 4) the aspect of recognizing the emotions of others and 5) aspects of fostering relationships. The aspect of recognizing self-emotion is the ability to recognize the emergence of one's own emotions. The aspect of managing emotions is the ability to manage your feelings.

Table 2. Classification of Student Self-efficacy Scores

\begin{tabular}{llll}
\hline Score Range & Category & Total (Student) & Percentage (\%) \\
\hline $\mathbf{1 2 5}-\mathbf{1 4 8}$ & Very High & 37 & 11 \\
$\mathbf{1 0 3}-\mathbf{1 2 4}$ & High & 172 & 51 \\
$\mathbf{8 1 - \mathbf { 1 0 2 }}$ & Medium & 116 & 35 \\
$\mathbf{5 9}-\mathbf{8 0}$ & Low & 9 & 3 \\
$\mathbf{3 4}-\mathbf{5 8}$ & Very Low & 1 & 0 \\
Total & & 335 & 100 \\
\hline
\end{tabular}

Table 2 shows the variation in the level of self-concept held by students majoring in Guidance and Counseling at universities throughout Yogyakarta in 2017/2018 academic year. Based on the data in the table it can be seen that there are 1 students or $0 \%$ who have self-efficacy in the very low category, 9 students or $3 \%$ categorized low, 126 students or $35 \%$ moderate category, 172 students or $51 \%$ categorized high and 37 students or $11 \%$ categorize very high. The tendency of self efficacy aspect of the student of Guidance and Counseling at university in Yogyakarta year 2017/2018 can be observed through three aspects: 1)challenging task orientation 2)facing challenges and 3) persistence reach the goal 4) confidence to achieve success 5)strategy to face challenges 6) improve the performance.

Table 3. Classification of Student Behaviour Prosocial Scores

\begin{tabular}{llll}
\hline Score Range & Category & Total (Student) & Percentage (\%) \\
\hline $\mathbf{1 2 5}-\mathbf{1 4 8}$ & Very High & 45 & 13 \\
$\mathbf{1 0 3}-\mathbf{1 2 4}$ & High & 158 & 47 \\
$\mathbf{8 1 - \mathbf { 1 0 2 }}$ & Medium & 119 & 36 \\
$\mathbf{5 9 - 8 0}$ & Low & 12 & 4 \\
$\mathbf{3 7}-\mathbf{5 8}$ & Very Low & 1 & 0 \\
Total & & 335 & 100 \\
\hline
\end{tabular}

Table 3 shows the variation in the level of prosocial behaviour held by the students of Guidance and Counseling at the University of Yogyakarta in the academic year 2017/2018. Based on the data in the table it can be seen that there are students 1 or $0 \%$ who have prosocial behaviour in the very low category, 12 students or $4 \%$ categorized low, 119 students or $30 \%$ categorized medium, 158 students or $47 \%$ 
categorized high and 45 students or $13 \%$ categorized very high. The tendency of interpersonal communication aspect of the students of Guidance and Counseling at the university in Yogyakarta for the academic year 2016/2017 can be observed through five aspects: 1) sharing 2) cooperative 3) donating 4) helping 5) honesty.

Table 4. Classification of Student Interpersonal Conflic Management Scores

\begin{tabular}{llll}
\hline Score Range & Category & Total (Student) & Percentage (\%) \\
\hline $\mathbf{7 4}-\mathbf{8 8}$ & Very High & 31 & 9 \\
$\mathbf{6 1}-\mathbf{7 3}$ & High & 107 & 32 \\
$\mathbf{4 8}-\mathbf{6 0}$ & Medium & 161 & 48 \\
$\mathbf{3 5}-\mathbf{4 7}$ & Low & 35 & 10 \\
$\mathbf{2 2}-\mathbf{3 4}$ & Very Low & 0 & 0 \\
Total & & 335 & 100 \\
\hline
\end{tabular}

Table 4 shows the tendency of interpersonal conflic management that students have in Counseling Guidance at university in Yogyakarta academic year 2017/2018. Based on the table, it is known that there are 0 students with very low interpersonal conflic management tendency, 35 low categorized students, 161 middle-class students, 107high categorized students and 31 students are in a very high category. Furthermore, the percentage of the data can be seen in Figure 5 page 119.

Based on the data in the table and the picture can be seen that there are 0 students or $0 \%$ who have social adjustment ability in very low category, 35 students or $10 \%$ categorized low, 161 students or $48 \%$ moderate category, 107 students or 32\% categorized high and 31 students or $9 \%$ are categorized as very high. The tendency of interpersonal conflic management aspect of student Guidance and Counseling at university in Yogyakarta year 2017/2018 can be observed through 3 aspects, namely: 1) collaboration and 2) compromise 3) accomodation.

Based on the data obtained then can be done the analysis of the influence of emotional intelligence, self-efficacy and prosocial behaviour to the interpersonal conflic managementof students Guidance and Counseling. The calculation results can be seen in the following table:

Table 5. Model Summary Partial Regression Test of Emotional Intelligence, Self efficacy and prosocial behaviour to Student interpersonal conflic management.

Model Summary

\begin{tabular}{|c|c|c|c|c|c|c|}
\hline Variabel & & $\mathbf{R}$ & $\begin{array}{c}\mathbf{R} \\
\text { Square }\end{array}$ & $\mathbf{F}$ & $\mathbf{p}$ & $\begin{array}{c}\text { Significant } \\
\text { level }\end{array}$ \\
\hline $\begin{array}{l}\text { Emotional Intelligence, } \\
\text { Prosocial Behaviour }\end{array}$ & Self-Efficacy, & 0,559 & 0,313 & 50,273 & 0,000 & $\begin{array}{l}\text { Very } \\
\text { significant }\end{array}$ \\
\hline
\end{tabular}

a. Predictors: (Constant), Emotional Intelligence, Self-Efficacy, Prosocial Behaviour

\section{Conclusions}

In terms of age and stages of student development, guidance and counseling students at the University of Yogyakarta in the academic year 2017/2018, in this case, is a student of the 4 semester, belonging to the final teenage group. The time span of the transitional period from adolescence to adulthood is so short that students in this period have special characteristics that differ from the period before and after.

The development of late teens that briefly affects the ability to make interpersonal conflic management in the environment where they are. Moreover, Yogyakarta is a student city, where students come from all over Indonesia which of course requires good social adjustment ability. Good social adjustment skills will help students to merge with others who have different tribes, residence, and language brought from home. 
Together variables of emotional intelligence, self efficacy and prosocial behaviour give a significant contribution to the interpersonal conflic management ability of students. The higher the emotional intelligence, the more positive self efficacy and the higher the prosocial behaviour, the higher the students' interpersonal conflic management ability. This is caused by the aspects that support the improvement of interpersonal conflic management ability of students supported positively from the variable of emotional intelligence, self efficacy, and prosocial behaviour.

Based on the results of the discussion can be concluded that emotional intelligence, self efficacy, and prosocial behaviour together affect the interpersonal conflic management of students Guidance and Counseling at the University of Yogyakarta in the academic year 2017/2018.

\section{References}

Albert Bandura. (1994). Self Efficacy: Toward Unifying Theory.

Goleman, D.,.(1995).Emotional Intelligence:Why It Can Matter More Than Iq.Usa:Bantam Books

Kilmann, R. H., \& Thomas, K. W. (1975). Interpersonal Conflict-Handling Behavior As Reflections Of Jungian Personality Dimensions. Psychological Reports. 37: 971-980.

Papalia, D. E., Old s, S. W., \& Feldman, R. D. (2009). Human Development PerkembanganManusia. Jakarta: SalembaHumanika.

Santrock, J. W. (2003). Adolesence: PerkembanganRemaja. Jakarta:Erlangga.

Winkel, W. S., \&Hastuti, S. (2006). Bimbingan Dan Konseling Di InstitusiPendidikan (EdisiRevisi, CetakanKelima).Yogyakarta :Universitas 